\title{
CHEMICAL COMPOSITION AND ANALGESIC ACTIVITY OF THE LEAVES AND BRANCHES OF Marlierea Tomentosa CAMB.
}

\author{
Karina Louise S. Messias, Fátima de Campos-Buzzi, Luiz G. O. Fischer, Ângela Malheiros, Franco Delle Monache e \\ Valdir Cechinel Filho* \\ Núcleo de Investigações Químico-Farmacêuticas, Centro de Ciências da Saúde, Universidade do Vale do Itajaí, CP 360 , \\ 88302-202 Itajaí - SC, Brasil
}

Recebido em 1/2/08; aceito em 30/4/08; publicado na web em 22/9/08

\begin{abstract}
This paper describes the isolation of five phytoconstituents from Marlierea tomentosa. The triterpenes $\alpha$-amyrin (1) and $\beta$-amyrin (2), and the flavonoids quercitrin (3) and isoquercetin (4), were isolated from the leaves. The branches afforded the triterpene arjunolic acid (5). The antinociceptive activity of crude extract, fractions and compound $\mathbf{5}$ were tested using the writhing and formalin tests in mice. The crude extract, some fractions, particularly dichloromethane and butanol (leaves), ethyl acetate (branches) and arjunolic acid (5) ( $81.2 \%$ inhibition) were more active against the writhing test than the two reference drugs, acetylsalicylic acid and indomethacin.
\end{abstract}

Keywords: Marlierea tomentosa; analgesic activity; triterpenes.

\section{INTRODUCTION}

The genus Marlierea belongs to the Myrtaceae family and grows in tropical and subtropical areas. The Myrtaceae family includes around 140 genus and 3000 species. ${ }^{1}$ Some studies of the genus Marlierea show that these plants are a rich source of bioactive compounds, especially flavonoids. In the leaves of $M$. grandifolia, for example, the presence of flavonoids quercetin and quercetrin was reported, as well as other phenolic compounds. ${ }^{1}$ Marlierea tomentosa Camb. is commonly known in the South of Brazil as guaparanga, garapuruva or garapuruna. Its leaves are used sometimes in folk medicine to treat several disorders, including pain and infections.

In the present study, we have analyzed the chemical composition of $M$. tomentosa leaves and branches and examined the possible analgesic effects of some fractions (hexane, dichloromethane, ethyl acetate and butanol) and of one isolated component, arjunolic acid (5) using the writhing and formalin tests in mice. In addition, we have included, for the purposes of comparison, the results of two reference drugs, acetylsalicylic acid and indomethacin.

\section{RESULTS AND DISCUSSION}

In order to isolate the main active principles present in $M$. tomentosa, the crude methanolic extract obtained by maceration with methanol, from the leaves, was partitioned with solvents of increasing polarities: $n$-hexane, dichloromethane, ethyl acetate and butanol, respectively.

The hexane and dichloromethane fractions were combined to furnish the triterpenes $\alpha$-amyrin (1) and $\beta$-amyrin (2) at a proportion of proportion 7:3, evidenced on the basis of NMR spectroscopic data interpretation. The ethyl acetate fraction led to the isolation of two known flavonoids, identified as quercitrin (3) and isoquercetin (4). Similarly, the crude extract from the branches furnished the same fractions as those indicated above, but only the hexane fraction has been studied so far, furnishing the triterpene arjunolic acid (5). All the isolated compounds were identified on the basis of analyses of

*e-mail: cechinel@univali.br melting point, IR spectra, ${ }^{1} \mathrm{H}$ and ${ }^{13} \mathrm{C}$ NMR spectra which are identical to those reported in the literature. Compounds (1-4) were confirmed by co-TLC with authentic samples.

The triterpenes $\alpha$-amyrin (1) and $\beta$-amyrin (2) are common in plants and these compounds previously demonstrated several types of biological effects, including antinociceptive, ${ }^{2}$ gastroprotective ${ }^{3}$ and antiinflammatory ${ }^{4}$ properties. Recent studies indicate that this mixture inhibits visceral nociception, as well as attenuating capsaicin-induced acute pain. ${ }^{5,6}$ The biological actions of flavonoids quercitrin (3) and isoquercetin (4) are well-documented, and some studies conducted at our laboratories have shown analgesic effects in distinct animal models of nociception. ${ }^{7-9}$ Triterpene arjunolic acid (5) was previously isolated from other plants of the genus Myrtaceae, including Eugenia florida ${ }^{10}$ and Melaleuca alternifolia, ${ }^{11}$ and a few biological properties are cited in the literature. ${ }^{12-16}$ Table 1 shows the results of analgesic activity of extract and fractions from $M$. tomentosa (leaves and branches) against the writhing test, administered intraperitoneally, at $10 \mathrm{mg} / \mathrm{kg}$, which indicates that some of them exhibit pronounced effects. The most promising result was demonstrated by dichloromethane fraction, which caused inhibition of $91.1 \pm 3.2 \%$, whereas the reference drugs acetyl salicylic acid and indomethacin, caused inhibition of just $18.0 \pm 4.0$ and $45.7 \pm 2.0 \%$, respectively, in the same model and dose.

Considering that the main substances evidenced in the leaves were already described in literature regarding their analgesic potential, like compounds $\alpha$-amyrin (1), $\beta$-amyrin (2), and the flavonoids quercitrin (3) and isoquercetin (4), we have not included these compounds in this study. For this reason, the arjunolic acid (5) was evaluated here against two classical models of pain in mice: writhing and formalin tests. It produced potent analgesic action in different animal models in vivo when administered intraperitoneally. When evaluated against the writhing test, compound (5) caused a high level of inhibition (81.2\%) at $10 \mathrm{mg} / \mathrm{kg}$ (i.p.) (Table 1), whereas the reference drugs were less active in the same dose and pharmacological model. Facundo and coworkers ${ }^{17}$ verified that 5 obtained from Combretum leprosum exhibits anti-inflammatory, anticholinestereasic and antinociceptive activities. Regarding the last one, it inhibited the acetic acid-induced constrictions by 30.3 at $10 \mathrm{mg} / \mathrm{kg}$, via oral, which extend our observations about the analgesic profile of this compound. 
Table 1. Antinociceptive action of crude extracts, fractions and arjunolic acid (5) from $M$. tomentosa and two reference drugs against acetic acid-induced abdominal constriction in mice $(10 \mathrm{mg} / \mathrm{kg}$, i.p.)

\begin{tabular}{lc}
\hline Treatment & Inhibition $(\%)^{\mathrm{a}}$ \\
\hline Crude extract (leaves) & $43.0 \pm 2.8^{* *}$ \\
Hexane fraction (leaves) & $19.9 \pm 5.1$ \\
Dichloromethane fraction & $91.1 \pm 3.2^{* *}$ \\
(leaves) & $44.4 \pm 5.9^{* *}$ \\
Ethyl acetate fraction (leaves) & $71.2 \pm 2.2^{* *}$ \\
Butanol fraction (leaves) & $38.0 \pm 6.7^{* *}$ \\
Crude extract (branches) & $39.7 \pm 3.0^{* *}$ \\
Hexane fraction (branches) & $42.6 \pm 3.8^{* *}$ \\
Dichloromethane fraction & $70.5 \pm 2.3^{* *}$ \\
(branches) & $81.2 \pm 3.0 * *$ \\
Ethyl acetate fraction (branches) & $18.0 \pm 4.0^{*}$ \\
Arjunolic acid (5) & $45.7 \pm 2.0^{* *}$ \\
Acetylsalicylic acid & \\
Indomethacin &
\end{tabular}

${ }^{\text {a } A t ~} 10 \mathrm{mg} / \mathrm{kg} ; * \mathrm{P}<0.05 ; * * \mathrm{P}<0.01$. Each group represents the mean \pm S.E.M of 6 to 8 experiments.

When tested against the formalin-induced model $(10 \mathrm{mg} /$ $\mathrm{kg}$, i.p.), 5 caused moderate activity, with inhibition of 34.2 and $38.1 \%$ (Table 2) in relation to the first and second phase of pain, respectively, suggesting that it may be acting by some peripheral mechanism.

Table 2. Antinociceptive action of arjunolic acid (5) and indomethacin against formalin-induced pain in mice $(10 \mathrm{mg} / \mathrm{kg}$, i.p. $)$

\begin{tabular}{lcc}
\hline \multirow{2}{*}{ Treatment } & \multicolumn{2}{c}{ Inhibition (\%) } \\
& First phase & Second phase ${ }^{2}$ \\
\hline Arjunolic acid (5) & $34.2^{*}$ & $38.1^{* *}$ \\
Indomethacin & 10.0 & $70.0^{* *}$ \\
\hline
\end{tabular}

Each group represents the mean \pm s.e.m. of six experiments. ${ }^{1} 0-5$ min licking $(\mathrm{s}) ;{ }^{2} 15-30$ min licking $(\mathrm{s}) ; * \mathrm{P}<0.05 ; * * \mathrm{P}<0.01$

Another important finding was obtained in the hot plate test, by the lack of antinociceptive effect of compound 5 at $10 \mathrm{mg} / \mathrm{kg}$, administered intraperitoneally (results not shown). It is a technique that presents a selectivity for opioid derived analgesics. ${ }^{18}$

Although additional studies are required to elucidate the exact mechanism of antinociceptive properties of compound $\mathbf{5}$, the results observed in the formalin and hot plate tests strongly suggest that it acts in a non-opioid patway.

In conclusion, the data obtained in this study indicate that $M$. tomentosa leaves and branches have a significant antinociceptive effect in mice, which seems to confirm and justify the traditional use of this plant in folk medicine, as a analgesic agent.<smiles>CC1(C)CCC2(C(=O)O)CC[C@]3(C)C(=CCC4[C@@]5(C)CC(O)[C@@H](O)[C@](C)(CO)C5CC[C@]43C)C2C1</smiles>

(5)

\section{EXPERIMENTAL}

\section{Plant material}

Leaves and branches of $M$. tomentosa were collected in June 2003, at Morro do Baú, Ilhota (state of Santa Catarina, Brazil). The plant was identified by Prof. Dr. A. Reis (Department of Botany, Universidade Federal de Santa Catarina), and a voucher specimen was deposited at the Barbosa Rodrigues Herbarium (Itajaí) under number VC Filho 037.

\section{Phytochemical analysis}

Leaves and branches (800 $\mathrm{g}$ of each) of M. tomentosa were cut into small pieces and macerated separately with methanol, at room temperature, for approximately seven days. After solvent removal under reduced pressure, the crude extracts were preliminary analyzed by TLC (thin layer chromatography) and specific reagents, according to the previously described methodology. ${ }^{19}$

The crude extract (leaves; $34.07 \mathrm{~g}$ ) was then suspended in water and successively partitioned with hexane, dichloromethane, ethyl acetate and butanol, respectively, to obtain the respective fractions, according to the method previously described..$^{19,20}$

The hexane $(0.15 \mathrm{~g})$ and dichloromethane $(0.58 \mathrm{~g})$ fractions, when analyzed by TLC, showed similar profiles, and for this reason they were combined and chromatographed on a silica gel (Merck) column eluted with hexane:acetone gradient, resulting in a mixture of the triterpenes $\alpha$-amyrin (1) and $\beta$-amyrin (2) (21 mg).

Fractionation of ethyl acetate fraction ( $3.36 \mathrm{~g})$ using a silica gel (Merck) column eluted with chloroform:methanol gradient, led to the isolation of two known flavonoids, identified as quercitrin (3) (39 mg) and isoquercetin (4) (27 mg).

The crude extract (branches; $39.3 \mathrm{~g}$ ), obtained as described above, was also suspended in water and successively partitioned with hexane, dichloromethane and ethyl acetate. Hexane fraction (1.03 g) was chromatographed on a silica gel (Merck) column eluted with hexane:acetone gradient, resulting in the separation and purification of the triterpene arjunolic acid (5) (64 mg).

The purity of all the isolated compounds was examined by TLC using Merck silica pre-coated aluminum plates, with several solvent systems of different polarities. Spots were visualized by short-wave UV light, sulfuric anisaldehyde and $\mathrm{FeCl}_{3}$ reagents. The identification of isolated compounds was performed by analyses of melting point, IR spectra, ${ }^{1} \mathrm{H}$ and ${ }^{13} \mathrm{C}$ NMR spectra as well as the comparison of the physical data with those reported in the literature. The molecular structures of compounds (1-4) were confirmed by co-TLC, using authentic samples. The spectroscopic data of compound $\mathbf{5}$ are similar to those described in the literature. ${ }^{10,11}$

\section{Animals}

Swiss mice of both sexes (25-35 g) were housed in automatically controlled temperature conditions $\left(23 \pm 2^{\circ} \mathrm{C}\right.$ and $12 \mathrm{~h}$ light dark cycles). Food and water were freely available. The animals remained in the appropriate Univali laboratory until several hours before the experiments.

\section{Pharmacological assays}

\section{Abdominal constriction response caused by intraperitoneal} injection of diluted acetic acid

Abdominal constrictions were induced by intraperitoneal injection $(0.6 \%)$, according to the procedures described previously ${ }^{21}$ with minor modifications. The animals were pre-treated with the crude extract, 
fractions or arjunolic acid (5) from $M$. tomentosa $(10 \mathrm{mg} / \mathrm{kg})$ or standard drugs, intraperitoneally, $30 \mathrm{~min}$ prior to acetic acid injection. The control animals received a similar volume of $0.9 \% \mathrm{NaCl}(10 \mathrm{~mL} / \mathrm{kg}$, i.p. $)$. After the challenge, each mouse was placed in a separate glass funnel and the number of contractions of the abdominal muscles, together with stretching, was cumulatively counted over a period of $20 \mathrm{~min}$. Antinociceptive activity was expressed as the reduction in the number of abdominal contractions, comparing the control animals with the mice pretreated with the crude extract, fractions or arjunolic acid (5).

\section{Formalin-induced pain}

The procedure used was essentially similar to that described previously. ${ }^{22}$ Animals of the same strain were anaesthetized with ether, except when used to analyze the first phase of formalin-induced pain, and $20 \mu \mathrm{L}$ of $2.5 \%$ ( $0.92 \%$ formaldehyde), made up of PBS (phosphate buffered saline containing: $\mathrm{NaCl} 137 \mathrm{mM} ; \mathrm{KCl} 2.7 \mathrm{mM}$ and phosphate buffer $10 \mathrm{mM}$ ) was injected under the plantar surface of the left hindpaw. The animals were acclimatized to the laboratory for at least $24 \mathrm{~h}$ prior to the experiments. The initial nociceptive scores normally peaked after 5 min (first phase, representing the neurogenic pain), and after 15-30 min after the formalin injection (second phase, representing the inflammatory pain). ${ }^{22}$ The animals were pre-treated with saline $0.9 \%(10 \mathrm{~mL} /$ $\mathrm{kg}$, i.p.), or fractions and arjunolic acid (5) $(10 \mathrm{mg} / \mathrm{kg}$, i.p.) $60 \mathrm{~min}$ prior to formalin injection. After application of the intraplantar irritant, the animals were immediately placed in glass cylinders ( $20 \mathrm{~cm}$ diameter). The time spent by animals licking or biting the injected paw was timed with a chronometer and considered indicative of pain.

\section{Hot-plate test}

The hot-plate was used to estimate the latency of responses according to the method described by Eddy and Leimback ${ }^{23}$ with minor modifications. The temperature of the hot-plate was maintained at 56 $\pm 3{ }^{\circ} \mathrm{C}$. The animals $(n=8)$ were placed on glass funnels on the heated surface and the time between placing the animals and the beginning of licking paws or jumping were recorded as latency of response in non-treated animals (saline $10 \mathrm{~mL} / \mathrm{kg}$, i.p.) or animals treated with compound 5 (10 mg/kg, i.p.) animals.

\section{Statistical analysis}

The results are presented as mean \pm S.E.M., and statistical significance between the groups was analyzed by means of the $t$ test of variance followed by Dunnett's multiple comparison test. $\mathrm{P}$ values less than 0.05 were considered significant.

\section{ACKNOWLEDGMENTS}

The authors are grateful to CNPq, FAPESC-SC and ProPPEC/ UNIVALI for financial support. They also thank to Prof. Dr. A. Reis for the botanical identification and collection of plant material.

\section{REFERENCES}

1. Amaral, A. C. F.; Kuster, R. M.; Bessa, W. S.; Barnes, R. A.; Kaplan, M. A. C.; Wessjohann, L. A.; Biochem. Syst. Ecol. 2001, 29, 653.

2. Otuki, M. F.; Vieira-Lima, F.; Malheiros, A.; Yunes, R. A.; Calixto, J. B.; Eur. J. Pharmacol. 2005, 10, 253.

3. Oliveira, F. A.; Vieira Júnior, G. M.; Chaves, M. H.; Almeida, F. R.; Santos, K. A.; Martins, F. S.; Silva, R. M.; Santos, F. A.; Rao, V. S.; Planta Med. 2004, 70, 780.

4. Otuki, M. F.; Ferreira, J.; Lima, F. V.; Meyre-Silva, C.; Malheiros, A.; Muller, L. A.; Cani, G. S.; Santos, A. R. S.; Yunes, R. A.; Calixto, J. B.; J. Pharmacol. Exp. Ther. 2005, 313, 310.

5. Oliveira, F. A.; Costa, C. L.; Chaves, M. H.; Almeida, F. R.; Cavalcante, I. J.; Lima, R. C. Jr.; Silva, R. M.; Campos, A. R.; Santos, F. A.; Rao, V. S.; Life Sci. 2005, 77, 2942.

6. Lima Júnior R. C.; Oliveira, F. A.; Gurgel, L. A.; Cavalcante, I. J.; Santos, K. A.; Campos, D. A.; Vale, C. A.; Silva, R. M.; Santos, F. A.; Chaves, M. H.; Rao, V. S.; Santos, F. A.; Planta Med. 2006, 72, 34.

7. Meyre-Silva, C.; Yunes, R. A.; Delle Monache, F.; Santos, A. R. S.; Schmeling, L. O.; Gadotti, V. M.; Liz, F.; Cechinel Filho, V.; Z. Naturforsch. 2001, 56, 939.

8. Krogh, R.; Kroth, R.; Berti, C.; Madeira, A. O.; Souza, M. M.; Cechinel Filho, V.; Delle-Monache, F.; Yunes, R. A.; Pharmazie 1999, 54, 464.

9. Gadotti, V. M.; Schmeling, L. O.; Machado, C.; Liz, F. H.; Cechinel Filho, V.; Meyre Silva, C.; Santos A. R.; J. Pharm. Pharmacol. 2005, 57,1345 .

10. Junges, M. J.; Fernandes, J. B.; Vieira, P. C.; Fernandes, M. F. G. S.; Filho, E. R.; Fruhauf, M.; Baranano, A. G.; Rev. Pesquisa e Pósgraduação (Erechim-Brasil) 2000, 1, 13.

11. Vieira, T. R.; Barbosa, L. C. A.; Maltha, C. R. A.; Paula, V. F.; Nascimento, E. A.; Quim. Nova 2004, 27, 536.

12. Diallo, B.; Vahnhaelen-Fastre, R.; Konoshima, T.; Kozuka, H.; J. Nat. Prod. 1989, 52, 879.

13. Sumitra, M.; Manikandan, P.; Kumar, D. A.; Arutselvan, N.; Balakrishna, K.; Manohar, B. M.; Puvanakrishnan, R.; Mol. Cel. Biochem. 2001, 224, 135 .

14. Bhakuni, R. S.; Shukla, Y. N.; Tripathi, A. K.; Prajapati, V.; Kumar, S.; Phytother. Res. 2002,16, 68.

15. Djoukeng, J. D.; Abou-Mansour, E.; Tabacchi, R.; Tapondjou, A. L.; Bouda, H.; Lontsi, D.; J. Ethnopharmacol. 2005, 101, 283.

16. Kim, D. H.; Han, K. M.; Chung, I. S.; Kim, D. K.; Kim, S. H.; Kwon, B. M.; Jeong, T. S.; Park, M. H.; Ahn, E. M.; Baek, N. I.; Arch. Pharm. Res. 2005, 28, 550 .

17. Facundo, V. A.; Rios, K. A.; Medeiros, C. M.; Militão, J. S. L. T.; Miranda, A. L. P.; Epifanio, R. A.; Carvalho, M. P.; Andrade, A. T.; Pinto, A. C.; Rezende, C. M.; J. Braz. Chem. Soc. 2005, 16, 1309.

18. Abbott, F. V.; Franklin, K. B. J.; Pharmacol. Biochem. Behav. 1986, 24 , 319.

19. Ugaz, O. L.; Investigación Fitoquímica, Pontificia Universidad Católica del Peru, $2^{\text {nd }}$ ed., Fondo Editorial: Lima, 1994.

20. Cechinel Filho, V.; Yunes, R. A.; Quim. Nova 1998, 21, 99.

21. Collier, H. D. J.; Dinnen, L. C.; Johnson, C. A.; Schneider, C.; Br. J. Pharmacol. 1968, 32, 295.

22. Hunskaar, S.; Hole, K.; Pain 1987, 30, 103

23. Eddy, N. B.; Leimback, D.; J. Pharmacol. Exp. Ther. 1953, 107, 385. 